Gut, 1965, 6, 234

\title{
Macroautoradiography with radiophosphorus in cancer of the stomach
}

\author{
O. GREGOR, O. ANDRÝSEK, B. BEDNÁř, L. HANÍK, O. VANĚČKOVÁ, \\ AND L. SIISTEK
}

From the First Medical Clinic, the Medical Faculty, Charles University, Prague, Czechoslovakia

EDITORIAL SYNOPSIS A new technique for using radioactive phosphorus in the diagnosis of cancer of the stomach is described. There is a close correlation between the maximum concentration of radioactivity and the histological demonstration of malignant changes.

Metabolism is increased in malignant tissue which, therefore, accumulates a larger amount of ${ }^{32} \mathrm{P}$ than the healthy tissue of the same organ (Selverstone, Solomon, and Sweet, 1949). The increased activity in tumour cells is mainly due to the activity of ${ }^{32} \mathrm{P}$ bound metabolically to nucleic acids (Shahon, Aust, and Root, 1957; Tuttle, Erf, and Lawrence, 1941). It is thus understandable that after a single dose of ${ }^{32} \mathrm{P}$ more radioactivity can be found in the cells of malignant tissue than in those of healthy tissue.

These properties were demonstrated in animal experiments and by measuring the radioactivity of various organs in healthy subjects and patients (Jones, Chaikoff, and Lawrence, 1940; Kenney, Marinelli, and Woodard, 1941; Kelsey, 1951; Selverstone et al., 1949; Solopaeva, 1959), and have been used clinically in the diagnosis of cancer of the breast (Low-Beer, 1946; Low-Beer, Bell, McCorkle, and Stone, 1946), brain (Selverstone et al., 1949), and eye (Thomas, Harrington, and Bovington, 1958).

Our team has been working for a number of years on various aspects of precancerous conditions of the stomach (Gregor and Haník, 1962; Gregor, Štka, Bednář, and Jirásek, 1960; Gregor, Volek, and Voslářová, 1960; Gregor, Bednáŕ, Jirásek, Vosláfová, and Haník, 1962; Gregor, 1962; Gregor, Bednáŕ, Pavlovský, Voslářová, and Jirásek, 1962; Gregor, 1965; Haník, and Gregor, 1962; Holý and Gregor, 1959; Volek and Gregor, 1960; Volek and Gregor, 1963) but in order to find out whether ${ }^{32} \mathrm{P}$ could be used in the early diagnosis of these precancerous conditions of the stomach it was necessary first to verify data in the literature (Ackerman and Spratt, 1963; Ackerman, McFee, Santoro, and Wangensteen, 1961; Schulman, Falkenheim, and Gray, 1949; Nakayama, 1956a; Nakayama, 1956b; Shahon et al., 1957; Shifrin 1958) on the reliability of the method in already developed cancer of the stomach.
Apart from the clinical picture, the routine methods of investigating cancer of the stomach are mainly morphological, whether radiology, gastroscopy, cytology, or operation and histological examination, are being considered. We were therefore interested whether a metabolic-biochemical approach to the problem of using ${ }^{32} \mathrm{P}$ would be practicable. This work was thus an attempt to find the answer to two questions. 1 , Whether the maximum concentration of ${ }^{32} \mathrm{P}$ in malignant tissue also corresponds to the morphological criteria of malignant growth, and 2, whether radioactive phosphorus can be used in the differential diagnosis of cancer of the stomach.

\section{METHODS AND RESULTS}

${ }^{32} \mathrm{P}$ has a half-life of $14 \cdot 3$ days and its maximum betaradiation is $1.71 \mathrm{MeV}$, with an average of $0.695 \mathrm{MeV}$. The maximum penetration into tissue is $0.8 \mathrm{~cm}$.

The results of investigations made on nearly 50 patients were used in the evaluation. All patients were examined clinically, radiologically, and by gastroscopy. Twentyfour hours before operation each patient was given $500 \mu \mathrm{C}{ }^{32} \mathrm{P}$, in the form of sodium hydrophosphate, intravenously. The resected stomachs were evaluated by their immediate macroscopic appearance, by measuring radioactivity, and finally, histologically. Investigations were made on two groups of patients: a group of 24 patients with cancer of the stomach and a control group of 19 patients with peptic ulceration.

The investigation was carried out in four stages.

In the first, the preliminary stage, radioactivity was determined in dry substance obtained from operation material in six patients with cancer of the stomach and five controls with peptic ulceration. In all preparations the activity of a sample of tumour tissue was measured and compared with a sample from the healthy tissue of the same specimen using an end-window Geiger-Muller tube. The results are expressed as activity related to dry weight. 
The results of measurements in these specimens showed no definite increase in radioactivity in the dry matter from the tumour tissue as compared with that from the unaffected part of the gastric mucosa. This can probably be explained by the test samples containing non-malignant tissue from the deeper layers of the stomach with a large amount of connective tissue and musculature, in addition to mucous membrane with malignant changes.

In the second stage, direct measurements of radioactivity in the stomach and infiltrated glands were made at operation. These results were compared with measurements made on macroscopically healthy mucosa. A further five patients with cancer of the stomach were investigated in this way and four patients with peptic ulceration. Measurements were made under asceptic conditions with an end-window beta-tube with a screen limiting the entry opening to a diameter of $2 \mathrm{~cm}$.

When direct measurements were made in this way no significant differences of activity over the tumour and its surroundings were found when measured from the serous side of the stomach, probably because of the thick layer of non-tumorous tissue between the detector and the mucous membrane with malignant changes. On measuring radioactivity from the mucosal side through a gastrotomy, in nearly all cases twice or more the number of impulses were measured over the tumour as over the macroscopically unaffected tissue.

Attempts were also made at operation to determine whether there were metastases in the lymphatic glands by the same method, in order to be able to advise the surgeon on the question of extirpation. The results were not satisfactory. In this case also measurements can only be made from the outside and, in addition, we lack a suitable correlation for comparison.

Thus the results of the second stage of the investigation showed that the only suitable manner of detection is by access from the mucosal side of the stomach. Measuring during operation from the outside of the stomach cannot provide the surgeon with any useful information.

In the third stage macroautoradiography was carried out in 13 stomachs resected for malignant proliferation, in three resected for gastric polyps, and, for comparison, in 10 stomachs resected for peptic ulceration. The specimens were fixed in $10 \%$ formalin, exposed for 72 hours to an $x$-ray film sensitive on both sides. After standard developing, the places producing blackening of the emulsion were marked on the specimen and these sites examined histologically.

The autoradiographs were measured photodensimetrically, and, with the help of a standard, the degrees of blackening were expressed as relative ${ }^{32} \mathrm{P}$ concentrations. In each autoradiograph the lightest place, i.e., the concentration in an unaffected part, was taken as $100 \%$. Sites of maximum blackening correspond to the highest concentration in the tumour. The differences in these values were expressed in percentages (Fig. 1).

After making the autoradiograph, the specimens of stomach were examined histologically in a standard grid with squares of about $2 \cdot 5 \mathrm{~cm}$. Positive cancer findings were drawn into the grid scheme of the stomach on the assumption that positive areas on a correctly performed radiograph should coincide topically with the foci of cancer demonstrated histologically. This assumption was completely fulfilled. A high degree of blackening in the radiograph always corresponded to the presence of a focus of cancer or of tissue, which from the histological point of view, could be classified as a cancerous condition. In the control group, there was usually a zone of increased growth of regenerating mucosa round a peptic ulcer which coincided with a slight increase in radiation in the radiograph. A tumour was only found in places where signs of increased radiation were absent if it was necrotic. And conversely, slight increases in radiation intensity without histological changes in the mucosa were probably due to an accumulation of the gastric mucosa. It can thus be concluded that there is complete agreement between autoradiography and histological findings (Figs. 2-8), showing that under certain conditions ${ }^{32} \mathrm{P}$ could be used for the differential diagnosis of cancer of the stomach.

We therefore passed on to the further stage of trying to work out a method of diagnosing cancer of the stomach using ${ }^{32} \mathrm{P}$ which would be suitable for clinical practice.

From the work already done it was assumed that the introduction of a detector sufficiently close to malignantly proliferating mucous membrane would

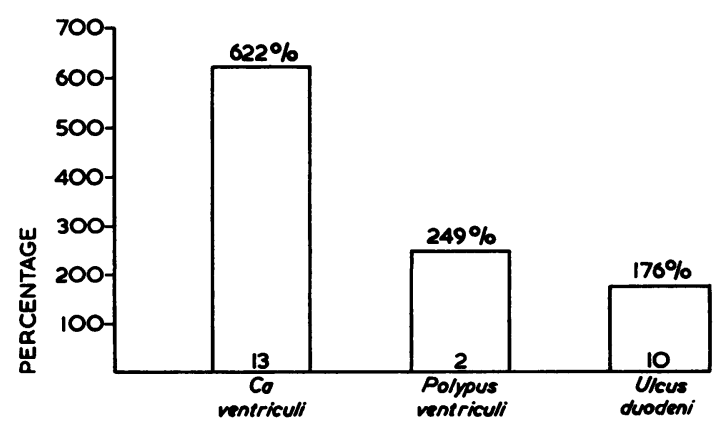

FIG. 1. The results of macroautoradiography expressed diagrammatically to show the relative concentrations of ${ }^{32} P$. 


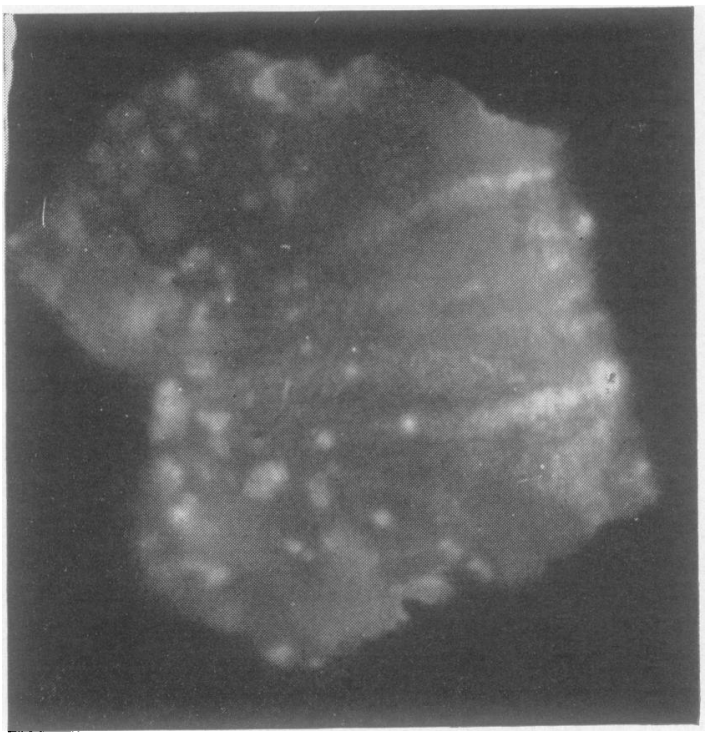

FIG. 2. Representative macroautoradiograph.

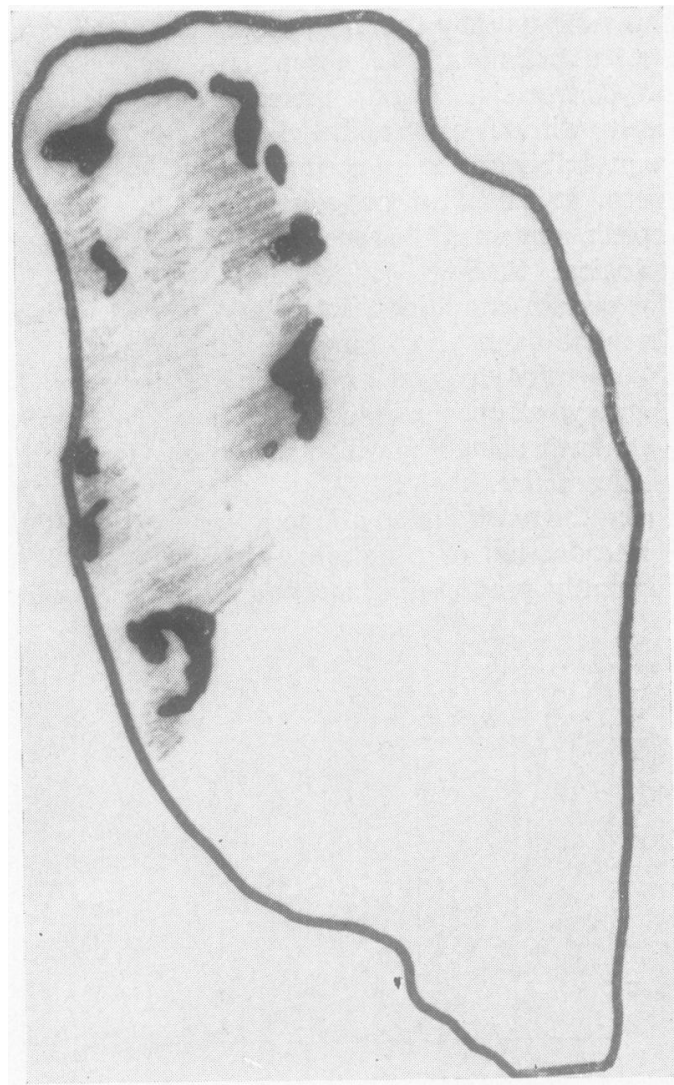

FIG. 5. Scheme of autoradiograph showing maximum blackening in case 3.

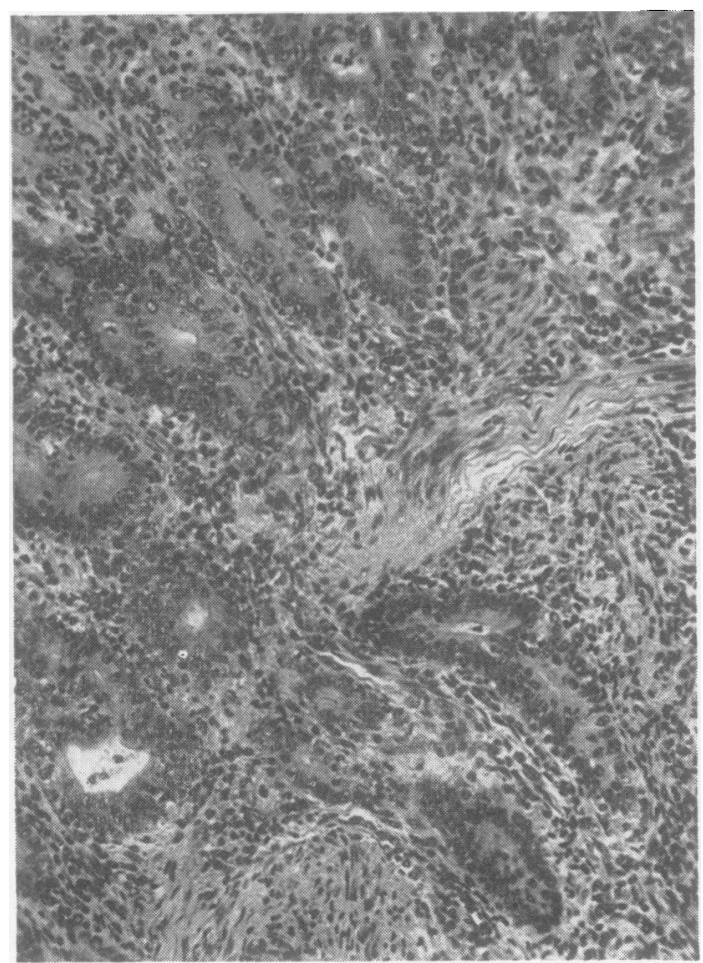

FIG. 3.

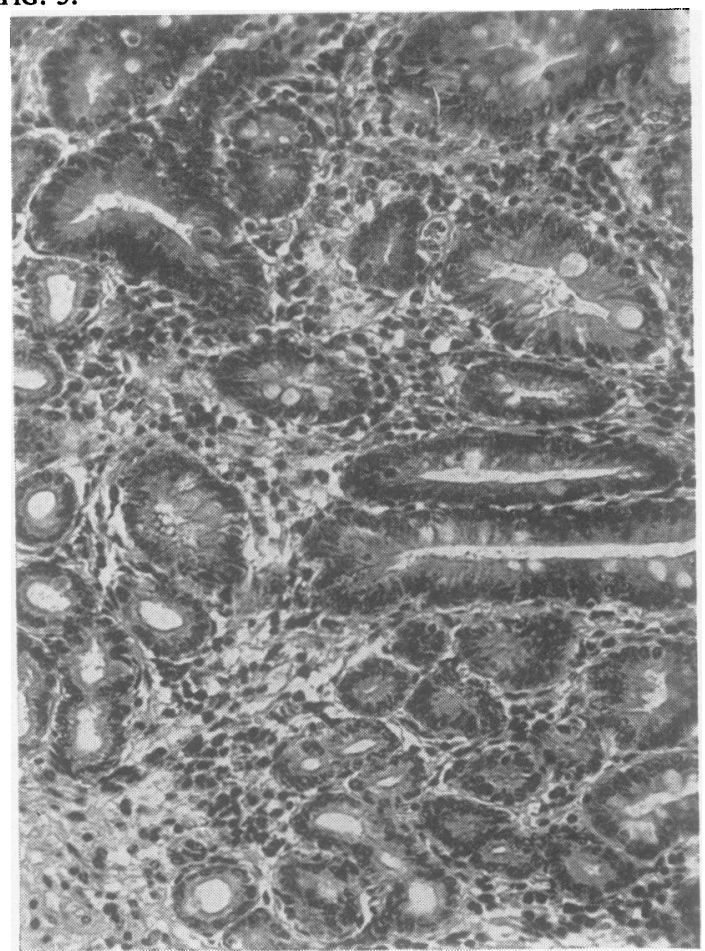

FIG. 4. 


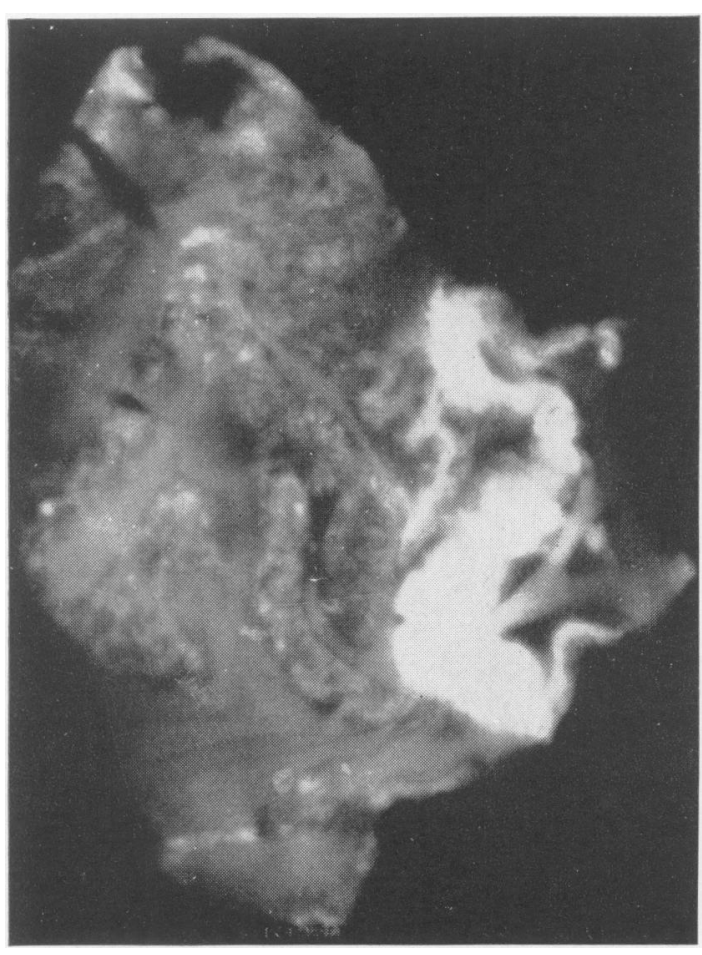

FIG. 6 .

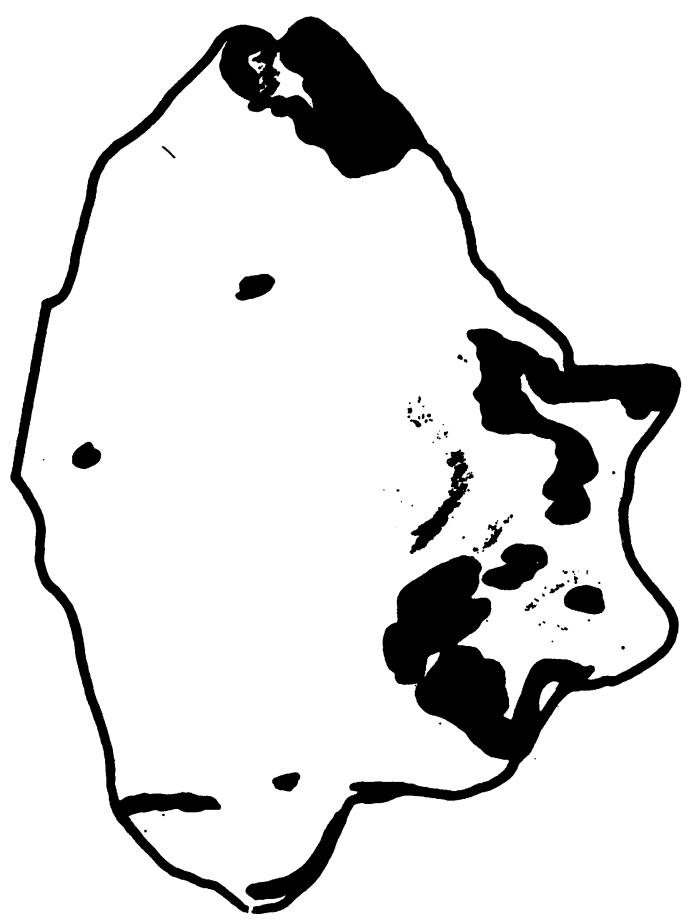

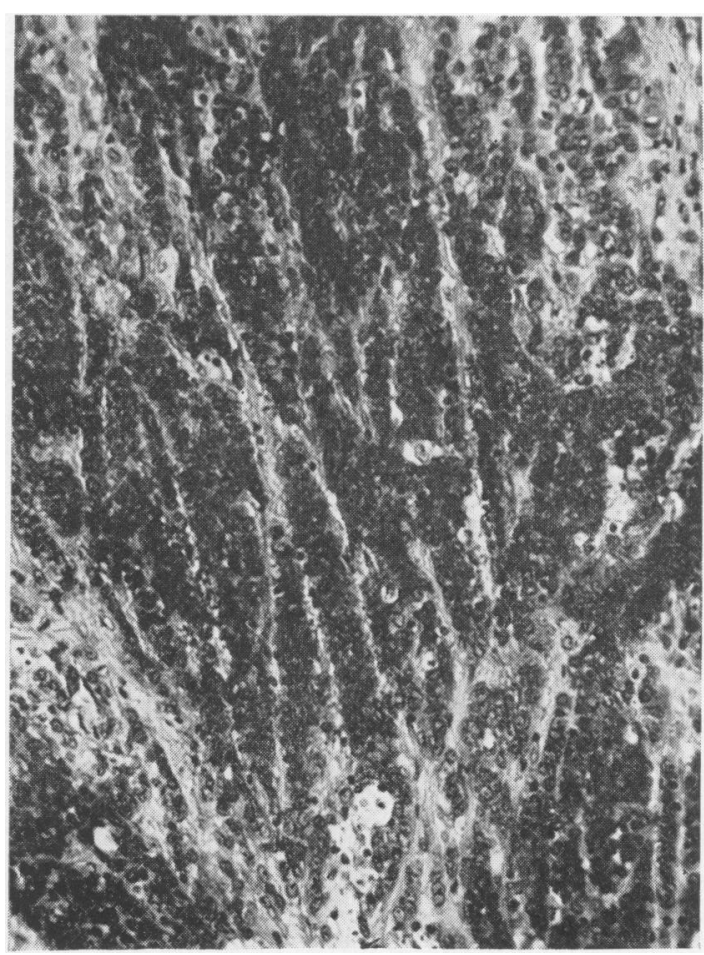

FIG. 7.

FIGS. 3, 4, and 7. Histological sections of cancer corresponding to the areas of maximum blackening. Compare Figs. 2 and 5.

FIG. 6. Macroautoradiograph of case 4 .

FIG. 8. Scheme of macroautoradiograph shown in Figure 6. 
FIG. 10.

Miniature GM-counter
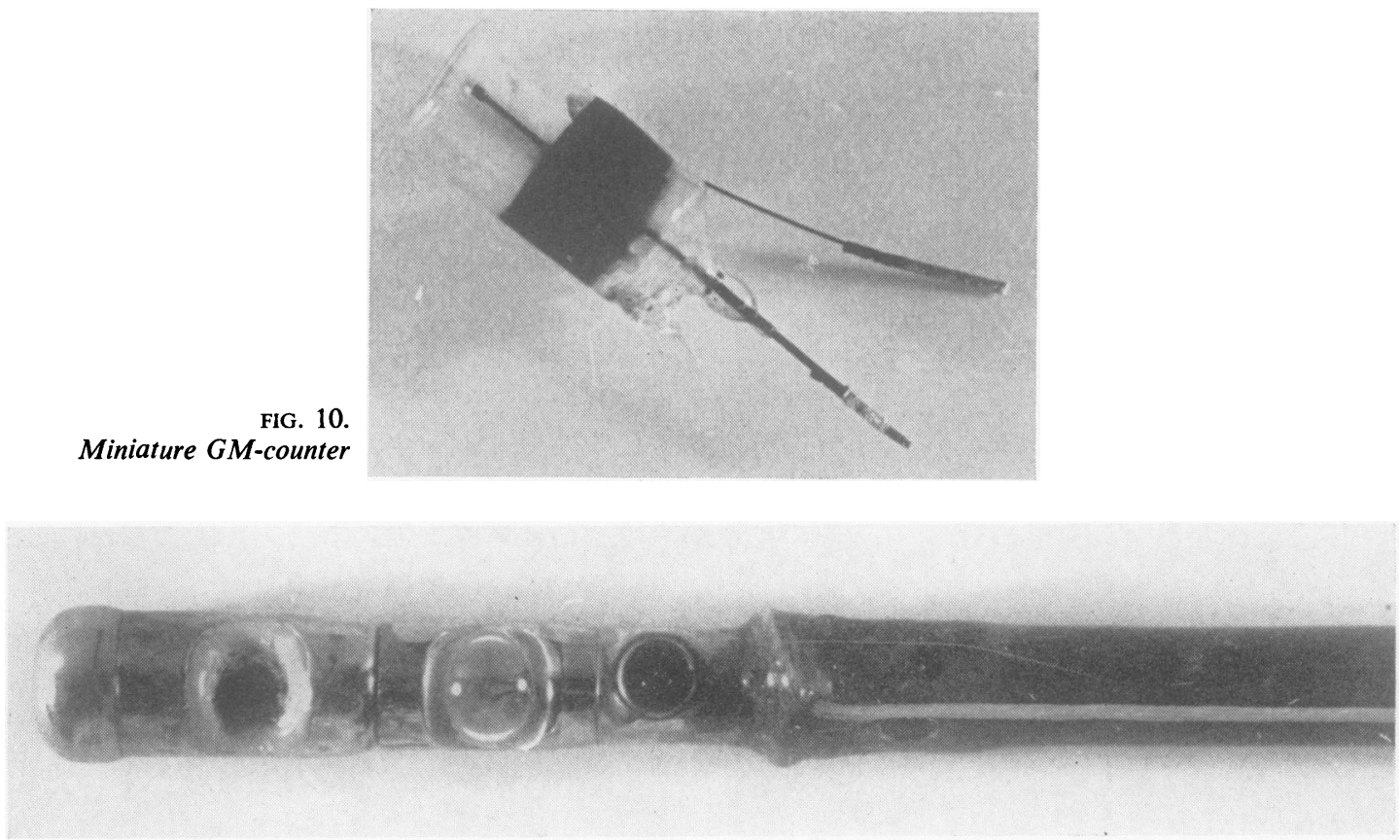

FIG. 11. Tip of 'radiogastroscope'.

make it possible to assess the presence of a cancer of the stomach from the large and significant differences in radioactivity. We attempted to do this in two ways, namely, by the introduction of a miniature Geiger-Muller tube fixed to a flexible rubber catheter under radiological control, and by introducing a miniature Geiger-Muller tube mounted on a gastroscope under visual control.

Measurements were made by a special miniature Geiger-Muller tube, enclosed in glass and filled with halogen, constructed especially for this purpose by the Research Department, Tesla, Liberec. The tube was fixed to the end of a flexible rubber catheter only slightly thicker than the normal duodenal tube. After introducing the tube under radiological control, the number of impulses was measured per 30 seconds. Beforehand, experiments were made to test the degree to which the small amount of barium gruel necessary to outline the stomach would affect measurements of radioactivity. The experiments were conducted on the stomachs of rabbits given radiophosphorus 24 hours previously. It was found that the decrease in the number of impulses with barium gruel is not greater than $10 \%$ and that it is, as a whole, equally distributed. Only when this had been completed did we proceed to investigations in man.

A patient with cancer of the cardia is given as an example. The tube could not be introduced deeper than to the cardia. At the stop-site the count was 260 impulses, and $3 \mathrm{~cm}$. orally to this the number of impulses fell to 110 . A further 10 to $20 \mathrm{~cm}$. orally to the cardia the number of impulses again rose to over 600 . At operation a stenosing cancer of the cardia was in fact found. Above the stenosis was a dilatation which caused the fall in impulses measured. At the sites of high activity in the region of the thoracic oesophagus tumorous infiltration was found which had previously escaped detection at oesophagoscopy.

For radiogastroscopy we used the Wolf-Schindler gastroscope. A metal cover was fixed to the tip of the gastroscope, with a diameter of $12 \mathrm{~mm}$. and $29 \mathrm{~cm}$. long, containing a Geiger-Muller tube with a side window in the same axis as the ocular (Figs. 9 and 10). The gastroscope modified in this way was named a radiogastroscope.

\section{DISCUSSION}

As the results of autoradiography were convincing, they permitted our advancing to clinical application. Two methods of clinical application are possible: a balloon fixed to a stomach tube as used by Ackerman and his team(Ackerman, et al., 1961; Ackerman and Spratt, 1963) in the U.S.A. or the device chosen by our group, i.e., radiotube or radiogastroscope.

Ackerman's idea is ingenious. It uses a photographic emulsion on a base of latex in place of a rubber balloon. The tube is introduced in a dark room, insufflated in the stomach with 600 to $900 \mathrm{ml}$. of air and left in situ for four hours. If the balloon comes to lie against the tumour, an area of definite blackening develops on it. 
The radiotube or radiogastroscope is introduced under direct control to the suspect site. The radiotube is introduced under the control of the $x$-ray screen, the radiogastroscope under direct visual control. The registration of the number of impulses then makes the findings objective.

The resolving of certain technical problems and further experience will be necessary before an evaluation can be made as to whether this method will be a contribution to clinical diagnosis in cancer of the stomach.

\section{CONCLUSION}

In conclusion we can return to the questions posed at the beginning of this paper. Our observations showed a close correlation between the maximum concentration of radioactivity and the histological demonstration of malignant changes in the gastric mucosa.

It was further shown that radioactive phosphorus can be used to diagnose cancer of the stomach, and the first results of pre-operative measurements using a radiotube and a radiogastroscope indicate that these methods may be suitable for practical application.

\section{REFERENCES}

Ackerman, L. V., and Spratt, J. S. Jr. (1963). Do adenomatous polyps become cancer? Gastroenterology, 44, 905-908.

Acke:man, N. B., McFee, A. S., Santoro, B. T., and Wangensteen, O. H. (1961). Radioautography in gastric cancer. Postgrad. Med., 29, 393-398.

Gregor, O. (1962). Problems of modern diagnosis of gastric cancer. In Abstracts of Papers, VIIIth International Cancer Congress, Moscow, p. 269. Medgiz, Moscow.

__ (1965). Včasná diagnoza rakoviny žaludku (Early diagnosis of gastric cancer). Státni zdrav. naklad. (Czechoslovak Medical Press). In the press.

—, Bednáŕ, B., Jirásek, A., Voslářová, Z., and Haník, L. (1962). Význam achlorhydrie jako funkěního korelátu atrofické gastritidy. Př́ispévek ke včasné diagnoze rakoviny žaludku. Cas. Lék. čes., 101, 893-895.

—_ Pavlovský, J, Vosláŕová, Z., and Jirásek, A. (1962). Indikace $\mathrm{k}$ resekci žaludku u praekanceróz. Př́ispévek ke včasné diagnóze rakoviny žaludku. Ibid., 101, 895-899.

and Haník, L. (1962). Žaludeční polypy jako praekancerosy. Přispévek $\mathrm{k}$ časnému rozpoznání rakoviny žaludku. Vnitřni Lék., 8, 145-151.
Gregor, Šetka, J., Bednář, B., and Jirásek, A. (1960). Gastrobiopsie u perniciózní anémie. Čas. Lék. čes., 99, 528-531.

—, Volek, V., and Voslářová, Z. (1960). Depistáž anacidit jako prekanceróz žaludku. Ibid., 99, 212-214.

Haník, L., and Gregor, O. (1962). DPA-reakce žaludeční štávy při rakovině žaludku. Přispěvek $\mathrm{k}$ včasné diagnoze rakoviny žaludku. Čs. Gastroent., Výż., 16, 509-512.

Holý, J., and Gregor, O. (1959). Rentgenové obrazy praekancerosních stavú žaludku u zhoubné chudokrevnosti. Vnitřni Lék., 5, 975-986.

Jones, H. B., Chaikoff, I. L., and Lawrence, J. H. (1940). Phosphorus metabolism of neoplastic tissues (mammary carcinoma, lymphoma, lymphosarcoma) as indicated by radioactive phosphorus. Amer. J. Cancer., 40, 243-250.

Kelsey, F. E. (1951). Radioactive isotopes in medical research, diagnosis, and therapy. J. Amer. med. Ass., 146, 1131-1134.

Kenney, J. M., Marinelli, L. D., and Woodard, H. Q. (1941). Tracer studies with radioactive phosphorus in malignant neoplastic disease. Radiology, 37, 683-690.

Low-Beer, B. V. A. (1946). Surface measurements of radioactive phosphorus in breast tumors as a possible diagnostic method. Science, 104, 399.

__, Bell, H. G., McCorkle, H. J., and Stone, R. S. (1946). Measurement of radioactive phosphorus in breast tumors in situ. Radiology, 47, 492-493.

Nakayama, K. (1956a). Diagnostic significance of radioactive isotopes in early cancer of the alimentary tract. Surgery, 39, 736-759.

_ (1956b). Die Frühdiagnose des Carcinoms des Verdauungstraktes durch $\mathrm{P}^{32}$. Z. Krebsforsch., 61, 22-30.

Schulman, J., Jr., Falkenheim, M., and Gray, S. J. (1949). The phosphorus turnover of carcinoma of the human stomach as measured with radioactive phosphorus.J. clin. Invest., 28, 66-72.

Selverstone, B., Solomon, A. K., and Sweet, W. H. (1949). Location of brain tumors by means of radioactive phosphorus. J. Amer. med. Ass., 140, 277-278.

Shahon, D. B., Aust, J. B., and Root, H. D. (1957). Localization of $\mathrm{P}^{32}$ as a diagnostic aid in gastrointestinal neoplasms. Surg. Forum, 7, 451-455.

Shifrin, S. S. (1958). O nakoplenii radioactivnogo fosfora v opukholiakh zheludochno-kishechnogo trakta. Éksp. Khir., 3, (5), 51-54.

Solopaeva, I. M. (1959). Primenenie metoda radioavtografii dlia issledovaniia vkliuchenii fosfora vopukholi i organy zhivotnykh. Biofizika, 4, 364-367.

Thomas, C. I., Harrington, H., and Bovington, M. S. (1958). Uptake of radioactive phosphorus in experimental tumors. III. The biochemical fate of $\mathbf{P}^{32}$ in normal and neoplastic ocular tissue. Cancer Res., 18, 1008-1011.

Tuttle, L. W., Erf, L. A., and Lawrence, J. H. (1941). Studies on neoplasms with the aid of radioactive phosphorus. II. The phosphorus metabolism of the nucleoprotein phospholipid and acid soluble fractions of normal and leukemic mice. J. clin. Invest., 20, 57-61.

Volek, V., and Gregor, O. (1960). Depistáž anacidit pomocí iontoměniču. Vnitřni Lék., 6, 674-677.

_- L (1963). Žaludex̌ni mléčná dehydrogenáza u achlorhydri Příspěvek $\mathrm{k}$ věasnému rozpoznání rakoviny žaludku $C s$. Gastroent. Výż., 17, 266-270. 